\section{What is already known on this topic}

Religious belief affects outcome of bereavement in families coping with the death of a child and in older people who are bereaved of a spouse

Research is often retrospective, and causal connections are difficult to establish

\section{What this study adds}

People who profess stronger spiritual beliefs seem to resolve their grief more rapidly and completely after the death of a person close to them than do people with no spiritual beliefs

Most palliative care units involve the family members and friends of the person dying; attention to spiritual matters may be an important component of this work

people who are having difficulty in readjusting to life after their loss.

We thank all participants and the Marie Curie staff who made the study possible. We acknowledge the contributions of Pippa Winton and Evelyn Blumenthal-counsellors at the Edenhall
Marie Curie Centre-who provided valuable emotional support to KW.

Funding: Leverhulme Trust.

Contributors: See bmj.com.

Competing interests: None declared.

Lauer ME, Mulhern RK, Schell MJ, Camitta BM. Long term follow-up of parental adjustment following a child's death at home or hospital. Cancer 1989;63:988-94.

2 McIntosh DN, Silver RC, Wortman CB. Religion's role in adjustment to a negative life event: coping with the loss of a child. J Pers Soc Psychol 1993;65:812-21.

3 Rosik $\mathrm{CH}$. The impact of religious orientation in conjugal bereavement among older adults. Int J Aging Hum Dev 1989;28:251-60.

4 King M, Speck P, Thomas A. The Royal Free interview for religious and spiritual beliefs: development and standardisation. Psychol Med 1995;25:1125-34.

5 Burnett P, Middleton W, Raphael B, Martinek N. Measuring core bereavement phenomena. Psychol Med 1997;27:49-57.

6 Zigmond AS, Snaith RP. The hospital anxiety and depression scale. Acta Psychiatr Scand 1983:67:361-70.

7 Stansfeld S, Marmot M. Deriving a survey measure of social support: the reliability and validity of the close persons questionnaire. Soc Sci Med 1992;35:1027-35.

8 Craig AR, Franklin JA, Andrews G. A scale to measure locus of control of behaviour. Br J Med Psychol 1984;57:173-80.

9 Clayton PJ. Bereavement and depression. I Clin Psychiatry 1990;51(suppl):34-40.

10 King M, Speck P, Thomas A. The effect of spiritual beliefs on outcome from illness. Soc Sci Med 1999;48:1291-9.

11 King M, Speck P, Thomas A. The Royal Free interview for spiritual and religious beliefs: development and validation of an expanded, self-report version. Psychol Med 2001;31:1015-23.

(Accepted 2 January 2002)

\title{
Medical students' compliance with simple administrative tasks and success in final examinations: retrospective cohort study
}

\author{
Neil Wright, M S Tanner
}

Sheffield Children's Hospital, Sheffield S10 2TH

Neil Wright

lecturer in paediatrics

M S Tanner

professor of

paediatrics

Correspondence to:

N Wright

N.P.Wright@

sheffield.ac.uk

BMJ 2002;324:1554-5
Medical students at the University of Sheffield are asked to provide a recent passport photograph at the start of their paediatric module. The pictures are collated, photocopied, and distributed to the wards, teachers, and hospitals within the paediatric programme. This makes identification easier and facilitates pastoral support and assessment.

We studied whether students who were unable to comply with simple administrative tasks-for example, supplying a photograph-were more likely to struggle and subsequently to fail their end of year examinations.

\section{Methods and results}

All students received a written and a verbal request for a photograph at registration for the module. In the introductory week, verbal reminders were given twice, and a list of those who had not supplied a photograph was displayed on a notice board, downstairs from the venue for the introductory course, on which the week's timetable is also posted. A photograph booth was situated in the students' union building, about 120 metres away from the venue for the introductory week.

In 1998 and 1999, a total of 393 students started their paediatric module. Passing the final examinations at the end of the year is prerequisite to entering the final year of the course. We checked whether or not a photograph had been provided by the end of the introductory week against the pass and fail lists.

A total of $366 \quad(93 \%)$ students handed in photographs, and of these 29 (8\%, 95\% confidence interval $6 \%$ to $11 \%$ ) failed or were disqualified from sitting the examination at the first attempt because they did not satisfactorily complete the clinical component of the course. Of the 27 students who failed to provide a photograph, $13(48 \%, 29 \%$ to $67 \% ; \mathrm{P}<0.001$, Fisher's exact test) failed the end of year examinations.

\section{Comment}

Almost half the students who failed to complete the basic administrative task of providing a recent photograph failed the end of year examinations; this highlights the importance of organisation and attitude in determining an individual's success. More sophisticated tools, such as a diagnostic inventory to investigate learning styles, support the view that disorganised learning is one of the most important predictors of examination failure. ${ }^{1}$

Three principal factors influence students' learning: the teaching, the learning environment or institution, and the individual student's learning style. ${ }^{2}$ Our 
findings suggest that the individual's approach and attitude are particularly important.

Attitude has an important influence on clinical competence and future clinical performance. ${ }^{3}$ It is beneficial to identify students whose learning style and approach are inappropriate, before they fail. Additional targeted help may be provided for these students.

Contributors: NW had the original idea for the study. Both authors wrote the paper. NW is guarantor.
Funding: No additional funding.

Competing interests: None declared.

1 Newble DI, Entwistle NJ, Hejka EJ, Jolly BC, Whelan G. Towards the identification of student learning problems: the development of a diagnostic inventory. Med Educ 1988;22:518-26.

2 Newble DI, Entwistle NJ. Learning styles and approaches: implications for medical education. Med Educ 1986;20:162-75.

3 Newble DI. Assessing clinical competence at the undergraduate level. Med Educ 1992;26:504-11.

(Accepted 6 February 2002)

\section{Drug points}

\section{Prolonged erections produced by dihydrocodeine and sildenafil}

David Goldmeier, Harpal Lamba, St Mary's Hospital, London W2 1NY At least 100 million tablets of sildenafil have been prescribed worldwide (Pfizer's data; personal communication). The use of sildenafil has only rarely been associated with priapism, ${ }^{12}$ although one such case was also associated with sickle cell trait. ${ }^{2}$ We report two cases of interaction between dihydrocodeine and sildenafil that resulted in prolonged erections.

Case 1-A 49 year old married man presented to our sexual function clinic with erectile dysfunction after a fall in which he sustained thoracic vertebral fractures. His partial paraplegia improved over the course of a year, after which he presented for treatment of erectile dysfunction. He was successfully treated with $100 \mathrm{mg}$ of sildenafil, which produced hard erections that detumesced immediately after intercourse. He later sustained a minor soft tissue injury to his right shoulder, for which he was initially given non-steroidal anti-inflammatory drugs. He continued to experience pain during the treatment, so his family practitioner changed the treatment to dihydrocodeine $30 \mathrm{mg}$ six hourly, which largely controlled the pain. While taking dihydrocodeine he also took $100 \mathrm{mg}$ of sildenafil. Although he had an orgasm and ejaculated, his erection remained hard for five hours and then subsided. Four days later he again took sildenafil while taking dihydrocodeine, after which he had an erection that lasted four hours. He has since stopped taking dihydrocodeine. He continues to use sildenafil $100 \mathrm{mg}$, which produces erections that subside immediately after orgasm.

Case 2-A 37 year old homosexual man with HIV was being followed up at our unit. His HIV viral load was 4125 RNA copies/ml and his CD4 cell count was 860 cells $/ \mathrm{mm}^{3}$ $(23 \%)$. He was not receiving antiretroviral treatment. The patient was referred to the sexual function clinic, where he was diagnosed as having psychogenic erectile dysfunction. He had recently been treated for moderate depression with cognitive behaviour therapy. While taking $100 \mathrm{mg}$ of sildenafil he had hard erections that subsided after orgasm. He later took dihydrocodeine $(30-60 \mathrm{mg}$ six hourly) for a soft tissue injury. During the first seven days of the analgesic treatment he took $100 \mathrm{mg}$ of sildenafil three times, which resulted in a prolonged erection lasting two to three hours after orgasm on each occasion. He continued to take the dihydrocodeine regularly for two more weeks, and the erection he had while taking sildenafil during this time detumesced immediately after orgasm.

The effects of opiates on sexual functioning are inconsistent and variable, but lowered testosterone concentrations, reduced sexual desire, erectile dysfunction, and delayed ejaculation have been frequently reported, particularly among chronic narcotic drug misusers. ${ }^{34}$
The acute opiate intake in our patients on sildenafil produced abnormally high cyclic guanosine monophosphate concentrations in peripheral nerve endings, which resulted in prolonged erections even after orgasm.

The manufacturers have no reports to date of prolonged erections in patients taking acute dose opiates and sildenafil, apart from our two cases. It is important when prescribing sildenafil to ask about current use of opiates, and to warn about such concurrent use in the future.

Funding: None.

Competing interests: DG has received grants from Pfizer and is a consultant to Eli Lilly.

Sur RL, Kane CJ. Sildenafil citrate-associated priapism. Urology 2000; $55: 950$.

2 Kassim AA, Fabry ME, Nagel RL. Acute priapism associated with the use of sildenafil in a patient with sickle cell trait. Blood 2000;95:1878-9.

3 Gulliford S. Opioid-induced sexual dysfunction.J Pharm Care Pain Symptom Control 1998;6:67-74.

4 Mirin SM, Meyer RE, Mendelson JH, Ellingboe J. Opiate use and sexual function. Am J Psychiatry 1980;137:909-15.

\section{Corrections and clarifications}

Male circumcision linked to lower rates of cervical cancer An editing slip occurred in this news article by Fred Charatan (27 April, p 994), in which we said that researchers tested for the presence of penile human papillomavirus DNA in 1520 men in the study, and found it in $1139(75 \%)$. It should have said that the researchers got a valid result in that number of subjects. The virus was not found in that number.

Homoeopathy use in NHS not justified In this news article by Mark Hunter (9 March, p 565), we said that a report from the NHS Centre for Reviews and Dissemination, York, maintained that there was no evidence to justify the use of homoeopathy in the NHS. We should have said that the report found that that there was insufficient evidence to warrant a significant change in the current provision of homoeopathy in the NHS

Driving and arrhythmias

The Driver and Vehicle Licensing Agency (DVLA) has asked us to update a point in this editorial by Helen Binns and John Camm (20 April, pp 927-8). The current standard requires only a two year (not five year, as stated in the article) moratorium on driving after an incapacitating event in relation to implanted cardioverter defibrillators. This new advice was published in December 2001 both in the panel minutes of the November panel meeting and in the DVLA handbook, At a Glance Guide to the Current Medical Standards of Fitness to Drive. Both these documents are available on the DVLA's website (www.dvla.gov.uk). 